Studia i Materiały, 2/2016 (22), cz. 2: 7-22

\title{
Factors Determining the Development of Product Eco-Innovations. The Evidence from Poland ${ }^{1}$
}

\author{
Magdalena Marczewska*
}

\begin{abstract}
The aim of this paper is to analyse and discuss the actions undertaken by Polish enterprises operating in the field of environmentally sound technologies to create and implement innovative, environmentally friendly products (i.e. environmental innovations, eco-innovations). The qualitative study examines the impact of the determinants, such as technology, market, regulation and firm specific factors, on the development of eco-innovative solutions of analysed companies. Based on the in-depth interviews conducted with forty selected companies, it is possible to specify the determinants of firms' eco-innovative activity and motivation factors for creating product eco-innovations in Poland. These are mainly market- and technology-related factors. This conclusion is in line with the studies emphasizing the role of market, technology and firm specific factors as the determinants of eco-innovations, but in opposition to the results supporting the thesis that regulatory aspect is highly important for the companies that create and develop environmentally friendly novelties.
\end{abstract}

Keywords: environmental innovation (eco-innovation), determinants of innovation, environmentally sound technologies, Poland, product innovation.

Submitted: 31.10.2016 | Accepted: 29.12.2016

\section{Czynniki wpływające na rozwój ekoinnowacji produktowych w Polsce}

Celem niniejszej publikacji jest analiza i omówienie działań podejmowanych przez polskie przedsiębiorstwa-dostawców technologii środowiskowych nakierowanych na tworzenie i rozwój innowacyjnych, przyjaznych dla środowiska produktów (tzw. innowacji ekologicznych, ekoinnowacji). Prowadzone badania jakościowe dotycza, między innymi, wptywu uwarunkowań, takich jak technologia, rynek, regulacje i cechy charakterystyczne przedsiębiorstwa na rozwój ekoinnowacyjnych rozwiazań $w$ analizowanych firmach. Na podstawie wywiadów pogtębionych, przeprowadzonych z przedstawicielami czterdziestu polskich firm, można określić czynniki determinujace ich ekoinnowacyjna dziatalność oraz opisać motywacje do tworzenia ekoinnowacji produktowych. Sa to przede wszystkim czynniki zwiazane z rynkiem i technologia. Wniosek ten jest zgodny z wynikami badań innych autorów, którzy podkreślaja ważna role rynku, technologii $i$ cech charakterystycznych firm $w$ tworzeniu ekoinnowacji. Wyniki przeprowadzonych badań nie potwierdzaja natomiast tezy podkreślajacej istotna role regulacji dla tworzenia ekoinnowacji produktowych.

\footnotetext{
Magdalena Marczewska - PhD, Faculty of Management, University of Warsaw.

Mailing address: Faculty of Management, University of Warsaw, ul. Szturmowa 1/3, 02-678 Warsaw, Poland; e-mail: marczewska.m.a@gmail.com.
} Ministry of Science
and Higher Education Republic of Poland
The creation of the English-language version of these publications is financed in the framework of contract No. 768/P-DUN/2016 by the Ministry of Science and Higher Education committed to activities aimed at the promotion of education. 
Słowa kluczowe: ekoinnowacja, źródła ekoinnowacji, technologie środowiskowe, Polska, innowacje produktowe.

Nadesłany: 31.10.2016 | Zaakceptowany do druku: 29.12.2016

JEL: O31

\section{Introduction}

In the last few years the issues of environmental responsibility and sustainable development have been arising in various debates amongst academic institutions, businesses and policy makers (Banerjee, Iyer and Kashyap, 2003; Chrząścik, Marciniuk-Kluska and Kluska, 2010; Triguero, Moreno-Mondéjar and Davia, 2013; Urbaniec, 2015). With respect to the problem of environment pollution and high costs of its decontamination, natural degradation prevention actions put forward the need for creating and widely implementing new practices for everyday life. Academics developed the idea of eco-efficiency (Kevin and Patrice, 1999), eco-labelling (Frieder, Dirk and Fabio, 2008), eco-effectiveness (Giancarlo, 2007), eco-design (Pinara and Jorg, 2005) and eco-innovation (Carrillo, Del Río and Könnölä, 2010; Horbach, Rammer and Rennings, 2012; Szpor and Śniegocki, 2012; Díaz-García, GonzálezMoreno and Sáez-Martínez, 2015), while enterprises discovered the need to adapt to the new trends (Aragon-Correa and Sharma, 2003; Jänicke, 2012). Given the challenges that arise due to climate change and global warming there is a need to ensure the widest possible development and diffusion of environmentally sound technologies in both developed and developing countries (Piotrowska, 2012; Correa, 2013).

The aim of this paper is to analyse and discuss the actions undertaken by Polish enterprises, product suppliers, operating in the field of environmentally sound technologies to create new environmentally friendly products (i.e. environmental innovations, eco-innovations). The study examines the impact of the determinants, such as technology, market, regulation and firm specific factors, on the development of eco-innovative solutions of analysed companies. Moreover, the research aims to describe country specific characteristics concerning the analysed topic. The research questions are the following:
1. What are the sources of eco-innovative activity undertaken by Polish companies-suppliers of environmentally sound technologies?

2. To what extent do the determinants of eco-innovations differ from the determinants of traditional innovation that are identified in the literature?

3. What are the country specific characteristics of the determinants of eco-innovations?

4. What are the companies' motivation factors in the process of developing environmentally sound technologies?

\section{Theoretical Framework}

\subsection{Defining Eco-Innovation}

Research on innovation seen from firms' perspective is grounded in theories of organization and management. The concept of innovation was introduced by Joseph Schumpeter (1939), who appreciated its important role in the economy. He believed that revolutionary business ideas that break down the current state of economic equilibrium by introducing a new combination of factors, are the driving forces of the economy. He named such phenomenon innovation, and he explained it using the approach of creative destruction (Schumpeter, 1939; Schumpeter, 1960). There are five types of novelties distinguished by Schumpeter: the introduction of new goods, the introduction of new methods of production, the opening of new markets, new sources of supply of raw materials and the introduction of new organizational structures of any industry (Schumpeter, 1960, p. 104).

There are many approaches that focus on the topic of innovations and provide their definitions and typology (Whitfield, 1979; Kotler, 2000; Rogers, 2003; Freeman, 1982; Drucker, 2004; Griffin, 1996; Porter, 2008). The variety of ways of describing innovation caused the need to introduce a clear definition of this phenomenon. 
Therefore, the Organization for Economic Co-operation and Development (OECD) proposed guidelines published in Oslo Manual that built a common understanding of innovation, its measuring and diffusion. According to the Manual, an innovation refers to the implementation of new or notably upgraded products, processes, goods, services, marketing methods or external relations. In order to help classify novelty, four main types of innovations have been listed: product innovations, process innovations, marketing innovations, organizational innovations (OECD, 2005).

The topic of eco-innovation is not yet well-established within the framework of economics and management. Although there are studies describing this issue, the research of this subject is still in early phase, especially in Eastern European countries, and there are not many researchers working on environmental innovations (Andersen, 2008). The phenomenon of eco-innovation is situated at the interface of two different sub-disciplines, environmental economics and innovation management (Rennings, 2000). In order to fully analyse it, multidisciplinary research would be very helpful.

Eco-innovation is a relatively new concept; therefore, before examining this phenomenon in Poland, it is necessary to define it. One of the first definitions of this issue was proposed by Claude Fussler and Peter James in 1996. According to them, it is an outstanding implementation of radical ideas, which will meet future needs (Fussler and James, 1996, p. 303). This concept has been later developed and clarified by one of its authors, Peter James, who describes it as a new product and process that significantly decrease environmental impact and at the same time provide value for business and customers (James, 1997). In its broadest form, ecological innovation is any novelty that reduces environmental harm (Kanerva, Arundel and Kemp, 2009). The most widely known and cited definition of eco-innovation is the one developed within the project Measuring Eco-Innovation on the basis of the definition of innovation proposed by OECD in Oslo Manual. It is the "production, assimilation or exploitation of a product, production process, service or management or business method that is novel to the organization (developing or adopting it) and which results, throughout its life cycle, in a reduction of environmental risk, pollution and other negative impacts of resources use (including energy use) compared to relevant alternatives" (Kemp and Pearson, 2007, p. 7). The authors' aim was to move away from the assumption that eco-innovation must be fundamentally aimed at reducing damage to the environment. Rene Kemp and Peter Pearson believe that a sufficient criterion for distinguishing eco-innovation from other types of innovation is that, as a result of an implementation of such solution, the harm of natural environment is smaller than in the case of the use of alternative solutions. The understating of the term eco-innovation is in line with this definition. The most important reviews concerning a broader discussion on ecoinnovation definitions is provided by other authors (Rennings, 2000; Kemp, 2010; Ekins, 2010).

Kemp and Pearson also developed a typology of eco-innovations that distinguished four categories of novelties: environmental technologies, organizational innovation, product and service innovation, and green system innovations (Kemp and Pearson, 2007).

There are many factors that influence companies' eco-innovative activity. They are not only environmental motivations, but also characteristics of the sector that company operates in, or its technological and development opportunities (CarrilloHermosilla, Del Río and Könnölä, 2009). Changes introduced within the company can result in the creation of eco-innovative solutions, especially when they are focused on product development, business strategy and marketing (Aragon-Correa and Sharma, 2003; Pujari, Wright and Peattie, 2003; Sharma, 2000). According to J. Elkington (1998), the company needs to make rational decisions in terms of balancing its financial, social and ecological performance, in order to introduce and operate in line with sustainable development philosophy.

The driving force behind the business willingness to invest in innovative activity facing the environment is, among others, the trend that promotes sustainable development (Cuerva, Triguero-Cano and Córcoles, 2013). It has become clear that sustainability means environmentalfriendly business, as well as long-lasting 
and significant changes in technology, infrastructure, lifestyles and existing institutions (Rennings, 2000). Until now it has been believed that technological innovation, together with the policy of sustainable development are key elements that are necessary to solve global environmental problems. Nowadays, however, the attention is also drawn to the important role of customers, who, through the implementation and widespread use of eco-innovative technological solutions, can contribute to a significant reduction of global pollution and the rational management and consumption of natural resources (Vergragt, Akenji and Dewick, 2014).

The research on eco-innovation concerns, above all, its definition (Rennings, 2000), drivers and determinants (Demirel and Kesidou, 2012; Zuzek, 2015), development (Pujari, Wright and Peattie, 2003; Prothero and McDonagh, 1992), variety (Carrillo-Hermosilla, Del Río and Könnölä, 2010), characteristics (Horbach, 2013; Węgrzyn, 2013), classification according to its impact on the environment (Horbach, Rammer and Rennings, 2012), management (Matejun, 2009; Przychodzeń, 2015) and its link with business performance (Woźniak, Strojny and Wojnicka, 2010; Seroka-Stolka, 2012; Siedlecka, 2014; Cheng, Yang and Sheu, 2014; Ziółko and Mróz, 2015).

\subsection{Determinants of Eco-Innovations}

Eco-innovations can be seen as one of the types of innovations. Because of this reason, their determinants can be traced on the basis of the models of innovations which have evolved over the past years, starting from the linear model introduced by Schumpeter (1939), through demandpush model (Schmookler, 1966; Rothwell and Gardiner, 1983), chain-linked model (Kline and Rosenberg, 1986), coupling model (Rothwell and Zegveld, 1985), network model, to the systemic perspective on innovations (Freeman, 1982). The analysis of these models leads to the conclusion that there are two crucial groups of innovation determinants: internal, i.e. determinants that are located inside the company, and external, i.e. factors that come from its organizational environment (Janasz and Kozioł, 2007) (see: Figure 1). R\&D companies' activities and knowledge resources accumulated in the enterprise are the most important amongst internal sources of innovation (Janasz and Leśkiewicz, 1995; Białon, 2010). In the midst of external drivers, the role of competitors and customers (Sosnowska, 2000) and also research carried out by universities, research and development centres and other research institutions (Penc, 1999) can be distinguished. The approach of dividing the determinants of innovations into two sets has been also applied by Peter Drucker (1992). As internal ones he lists: the unexpected, incongruities and process need. The next three sources are associated with changes in the business environment: changes in industry and market structure, demographics, changes in perception, and new knowledge (Drucker, 1992, p. 44).

Figure 1. Determinants of innovations

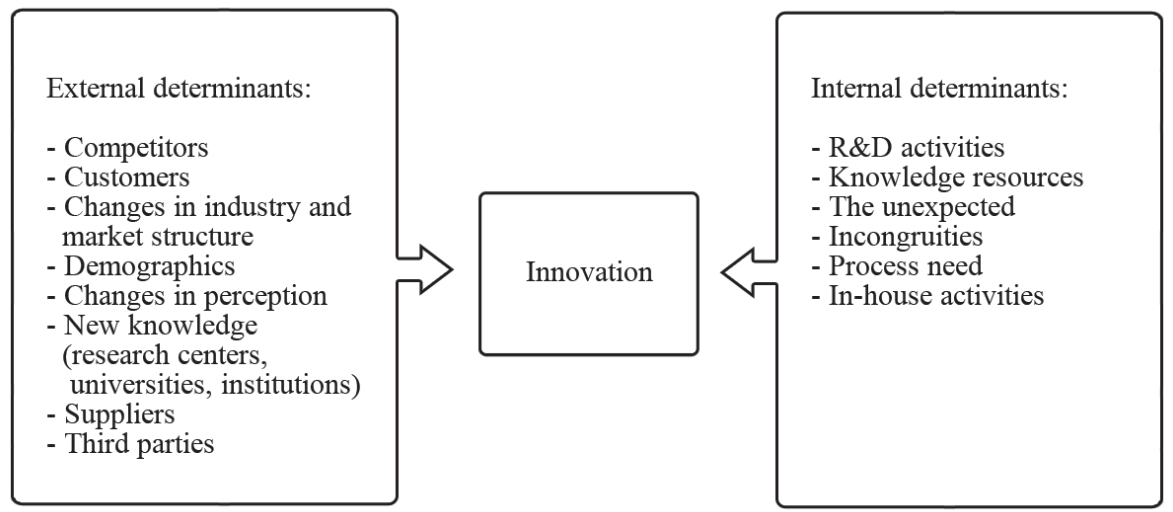

Source: own elaboration based on Tidd, Bessant and Pavitt (2005); Drucker (1992); Von Hippel (1988); Janasz and Leśkiewicz (1995); Białoń (2010); Penc (1999). 
Amongst other classifications of determinants of innovations, there is a concept introduced by Von Hippel (Von Hippel, 1988), according to which the three main sources of innovations are: customers, suppliers and third parties, such as research centres, universities. A similar approach has been proposed by Tidd, Bessant and Pavitt. These researchers listed suppliers, customers, in-house activities and basic research as the sources of developing the novelties (Tidd, Bessant and Pavitt, 2005, p. 171).

The researchers who focus on environmental innovativeness have developed industry specific classifications of determinants of innovations (Horbach, 2008; Belin, Horbach and Oltra, 2009; Cuerva, Triguero-Cano and Córcoles, 2013; Oltra, 2008; Cleff and Rennings, 1999; Del Val Segarra-Oña and Peiró-Signes, 2013; Zuzek, 2015). Although the overview of the literature shows that a similar set of drivers applies to general innovations and eco-innovations, in the case of environmental innovations the precise influence of each driver on the emergence of environmental friendly solutions is more difficult to evaluate. Therefore, some researchers argue that the analysis of environmental innovations should concentrate on the interactions between different drivers of innovativeness and at the same time on the relationships between competitiveness, companies' characteristics and environmental performance of firms (Oltra, 2008).
In the study conducted by Klaus Rennings (2000), the sources of eco-innovations are divided into three categories: technology push, regulatory pull and market pull. The first source consists of such factors as product quality, energy efficiency, product palette and material efficiency. The later one should be associated with existing environmental law, expected regulations and Occupational Safety and Health standards. The market pull determinants listed by Rennings are, among others, competition, labour costs, customer demand, image, market share and new markets.

Jens Horbach distinguished and described three categories of sources of eco-innovation, on the basis of their origin. There are eco-innovations stimulated by demand, supply, and policy and institutional factors. A detailed classification of these categories is described in Table 1.

In many recent studies the key concept of the determinants of environmental innovations consists of four main driving forces: technology, market, regulation and firm specific factors (Horbach, Rammer and Rennings, 2012) (see: Figure 2).

As already mentioned, it is difficult to assess which of these factors are the most important in the development of eco-innovations. Empirical research provides various points of view on this topic.

Technology push factors are essential drivers of eco-innovations. The evidence of this is presented in the research based on German panel data that revels that $R \& D$ activities that result in the improvement of

Table 1. Determinants of eco-innovation divided into categories

\begin{tabular}{|l|l|}
\hline \multicolumn{1}{|c|}{$\begin{array}{c}\text { Category of } \\
\text { determinants }\end{array}$} & \multicolumn{1}{c|}{ Determinant of eco-innovations } \\
\hline \multirow{2}{*}{ Supply side } & Technological capabilities \\
\cline { 2 - 3 } Demand side & Appropriation problem and market characteristics \\
\hline \multirow{3}{*}{$\begin{array}{l}\text { Institutional and } \\
\text { political influence }\end{array}$} & $\begin{array}{l}\text { Social awareness of the need for clean production; environmental } \\
\text { consciousness and preference for environmentally friendly products }\end{array}$ \\
\cline { 2 - 3 } & $\begin{array}{l}\text { Environmental policy (incentive-based instruments and regulatory } \\
\text { approaches) }\end{array}$ \\
\cline { 2 - 2 } & $\begin{array}{l}\text { Institutional structure: e.g. political opportunities of environmentally } \\
\text { networks }\end{array}$ \\
\hline
\end{tabular}

Source: Horbach (2008, p. 164).

Wydział Zarządzania UW ～DOI 10.7172/1733-9758.2016.22.1 
Figure 2. Determinants of eco-innovations

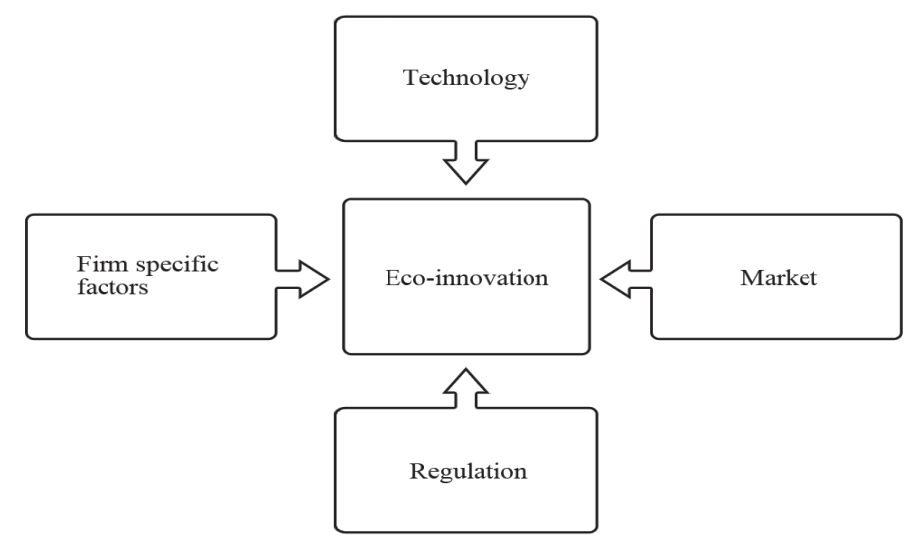

Source: Horbach, Rammer and Rennings (2012, p. 113).

firms' technological performance influence eco-innovativeness (Horbach, 2008).

Companies' access to significant, preferably limited resources can help to develop environmentally friendly solutions (Hart, 1995; Ryszko, 2016). The study of Demirel and Kesidou (2012), in line with the previous empirical findings, reveals that firm specific factors, such as organizational capabilities related to environmental management systems, are important in eco-innovations creation. What is more, these determinants affect environmental solutions development decisions and the level of firms' resources allocated to eco-innovation activities. This study provides also evidence that market demand factors, amongst which corporate social responsibility (CSR) and consumer needs and requirements, do not influence the level of investments in environmentally friendly products to a large extent. These factors are seen as important and companies are willing to respond to social needs with some minimum investment. However, these factors do not commit the companies to undertake outstanding actions in order to develop new solutions (Demirel and Kesidou, 2012). Such approach of companies is, in general, confirmed by some studies (Rehfeld, Rennings and Ziegler, 2007), but it is possible to find the evidence that customers can be very important in the process of developing eco-innovations. Such situation can take place only if the solution is perceived as adding value by customers (Kammerer, 2009).
The determinant of eco-innovations that is the most difficult to assess is the regulatory aspect. Some studies reveal that regulatory framework has a strong impact on firms' eco-innovative activity (Brunnermeier and Cohen, 2003; Rennings, 2000) and is necessary in order to support market pull and technology push factors since these two do not seem to be strong enough to drive eco-innovativeness (Cleff and Rennings, 1999). However, some researches claim that it should not be treated as the only factor that directly influences the development of eco-innovations (Oltra, 2008). It has also been found that existing regulations, contrary to expected ones, shape to some extent product and organizational eco-innovations. Future regulations have no significant impact on European companies' decisions to develop environmentally friendly solutions (Triguero, Moreno-Mondéjar and Davia, 2013).

To conclude the literature review, it should be pointed out that depending on geographical region and the type of environmental innovation, its origin can be assessed by analysing the technological compromises between various drivers and objectives of innovativeness (Oltra, 2008). Such approach is used here in the research on eco-innovations in Poland.

\section{Research Methods}

The empirical part of this research is based on in-depth, semi-structured interviews conducted with the representatives 
of selected 40 Polish companies operating in the field of environmentally sound technologies, within six areas:

- renewable energy sources (10 firms): manufacturers of solar collectors, briquetting machines, fuel cells, hydro power and biogas solutions,

- energy efficiency (9 firms): suppliers of technologies that support saving electricity and heat, solutions for passive houses, energy-efficient lighting solutions, heat pumps, media management systems for energy,

- waste management (9 firms): suppliers of solutions for treatment of hazardous waste and by-products of coal combustion, secure storage of liquid fuels, biomass gasification, processing plastics into liquid fuels,

- water and wastewater management (7 firms): suppliers of water treatment plants, water treatment solutions and drying of sewage sludge solutions,

- biodiversity protection (3 firms): suppliers of technologies for reclamation of lakes and barriers to protect fish,

- air protection (2 firms): suppliers of pollution emission reduction systems.

This qualitative sample was purposely chosen. The selected companies were the participants of the governmental project-competition, GreenEvo - Green Technology Accelerator, run by the Polish Ministry of Environment. All participants of the project were evaluated by independent experts in terms of their innovativeness, environmental effects of their products and development potential. Forty interviewed companies were the winners of the GreenEvo competition in 2010-2012.

The companies distinguish themselves from other environmentally sound technologies industry market players in Poland, as suppliers of own, eco-innovative products and as entities interested in international markets. Each interview was based on the same script, which contained a list of more than a hundred detailed, open questions. All of the interviewees were either company owners or managing board members, such as sales managers or product managers, thus they can be seen as well-informed reliable sources of information. In the case of some companies from the sample, interviews were conducted with more than one participant from the same company. The interviewers were allowed to interact freely with the interviewees in order to gather information on both, facts and their interpretation, along with personal opinions of respondents. That is why, during the interviews it was possible to discuss additional, relevant topics. The respondents were guaranteed anonymity. Interviews were carried out by several members of the research team (triangulation of researchers) in order to eliminate unconscious preferences of interviewers, and thus provide a better quality of research conducted (Flick, 2011). The interviews lasted on average 157 minutes ( 2 hours 37 minutes), but the longest one took 266 minutes (4 hours 26 minutes). The total time of all interviews was 6280 minutes (104 hours and 40 minutes). The interviews were recorded, transcribed, divided into topic-based text segments and coded into 77 detailed codes collected in the codebook. The codebook was the basis for analysis and interpretation of the qualitative data which was made in accordance with the grounded theory approach (Corbin and Strauss, 1990; Glaser and Strauss, 2006).

\section{Results of Empirical Research}

The interviews confirmed that the process of developing eco-innovative solutions is often long and complex. New technologies are usually the result of long-term work of many experts from different fields. Each innovative idea is established in different circumstances, that is why, it is difficult to describe one, precise approach to this issue. For this reason, the respondents were not able to clearly indicate one factor that influenced the development of their technology. In their statements several components were often pointed out. Moreover, the empirical research provides the evidence of motivations that led to the creation of eco-innovations. It is important to take into account that determinants and motivations are not the same. Motivations are the inspirations to take the effort and develop an environmental solution, while determinants specify the factors that directly influenced this development.

The determinants of eco-innovations distinguished by the interviewees can be divided into two groups: internal ones, related to the company and its potential, and external, such as its organizational environment, customers and competi- 
tors related. The former were considered more important, as 23 companies indicated that the development of eco-innovations depended on the knowledge and skills gathered within the company. However, external factors, such as inspiration from other market players, influence of the demand or cooperation with research centres, were indicated by 20 interviewees as the sources of eco-innovations. Since the research had been based on the semistructured interviews with open-ended questions, the interviewees were not provided with sample answers that could affect their statements. For this reason, the drivers of eco-innovations they recalled were not limited to any theoretical framework and exactly described the moment of their eco-innovative products creation. All the answers provided by the respondents are shown in Figure 3.

Figure 3. Determinants of product eco-innovations development in Poland

\begin{tabular}{|c|c|}
\hline External determinants & Internal determinants \\
\hline $\begin{array}{l}\text { - Identification of market } \\
\text { needs } \\
\text { - Inspiration from the } \\
\text { competition } \\
\text { - Product order placed by } \\
\text { the customer } \\
\text { - Wilingness to stand out } \\
\text { from the copetition } \\
\text { - Cooperation with uni- } \\
\text { versities (an initiative } \\
\text { of academic staff) } \\
\text { - Willingness to satisfy } \\
\text { customers' needs }\end{array}$ & $\begin{array}{l}\text { - Research } \\
\text { - Experience and skills of } \\
\text { innovation developers } \\
\text { - Idea }\end{array}$ \\
\hline
\end{tabular}

Source: own elaboration based on the interviews.

\subsection{Internal Determinants of Eco-Innovations}

The main stimulus that falls in this category is the research activity, based on the work and skills of companies' employees and conducted within it. Although 27 companies declared that they performed in-house research, around half of them admitted that such activity was the direct determinant of their technology creation and development. At the moment of working on the eco-innovation, companies were conducting research of various types. Most of them focused on technology development and product testing in their labora- tories which was performed by research teams inside the company, whose skills were based on previously gathered knowledge and experience. Some of the companies received assistance from external entities, collaborated with them co-operating or subcontracting research tasks. Such cases were relatively few. Only 2 interviewees followed this path of new solutions development.

The biggest group amongst the companies engaged in $R \& D$ was represented by both former or present academics and members of university project teams. In a few cases, the technology is the result of research initiated during the higher education of its inventor.

According to the interviews, 12 companies have developed eco-innovative technology without being influenced by or engaged in any research. Most of them developed a new solution on the basis of observing the performance of the previously existing solutions, after its adoption by the client, confronting this performance with the original objectives and introducing continuous modifications and improvements.

Another determinant, recalled by 3 companies, that influenced the development of eco-innovations by the Polish companiessuppliers of environmentally sound technologies was the result of past experiences of employees and firms' owners. Almost half of eco-innovation inventors previously worked in the environmental and advanced technology industries. More than one-third of them were employed in business and at the university at the same time. In addition, many employees gained experience in multinational companies. For people employed in the research units of higher education, scientific research at companies' level was a logical complement to their academic activities and a basis for the creation of eco-innovative technologies.

The last internal driver of eco-innovation, mentioned by only 1 interviewee, was a completely new idea that appeared in the minds of innovation creators. At the same time, people representing this company also declared that the process of innovation creation had been long and had been influenced by so many factors that it was difficult to list all of them.

In the opinion of interviewees, various types of their personal experience, not only 
related to education and business, contributed to the technology development. However, 95\% of interviewees (38 companies) confirmed that cooperation with universities or work in other companies had a positive impact on the performance and the speed of technology development, especially in terms of motivation.

\subsection{External Determinants of Eco-Innovations}

Among the external determinants of eco-innovations, the most important was the identification of market needs. On the basis of well-prepared market analysis, it was possible to easily identify not only potential customers but also competitors. The awareness of the market circumstances allowed for creating and developing innovative technology, and new ideas were adapted to the companies' organizational conditions. Interviewees admitted that both domestic and international markets were a stimulus for the development of new technological solutions.

Interviewed firms admitted that there were also three main motivations for their eco-innovation activity: competitors, customers and the business environment in a broad sense.

24 companies declared that creation of new technologies was inspired by similar solutions developed by other companies. Such inspiration was usually drawn by examining existing technologies available on the market in order to identify their functional and technical deficiencies and imperfections. According to some interviewees it is important to perform market observation to find imperfections and flaws in available technologies. They believe that the weaknesses of other market players are the best inspiration to create own eco-innovative solutions.

Among companies that inspired interviewed companies to develop product eco-innovations, competitors are the most important ones. 4 companies declare that they drew inspiration from competitors and this was the crucial factor in their technology development. Moreover, 2 interviewees indicate that their firms developed innovative environmentally friendly solutions in order to distinguish themselves from the competitors.

The creation of innovations can be motivated by customers, who, on the one hand, buy and use a product, and on the other, often share their comments and valuable knowledge about its functionality and performance with producers and suppliers. 26 companies admitted that clients often suggest an idea for a product, service, or technical improvement to them, and with such behaviour motivate them to seek for potential eco-innovation development opportunities. Information from customers has been received in many different ways. It is usually gathered during conversations with clients concerning their needs and expectations, as well as possibilities to satisfy such needs by new, potential features of eco-innovations. Some interviewees declared that their contact with customers was regulated in special contractual clauses which obliged users to provide information about technology performance.

3 companies reported that customers' behaviour had a direct influence on the development of their eco-innovation and could be seen as the determinant of companies' eco-innovative activity. This influence occurred when potential users asked the companies to develop a technology with special features that would better satisfy their needs. Enterprises were willing to work on such solution, and customers were happy to help in developing its functionality and features. The cases of such companies justify their fruitful and successful cooperation with the users. Within the researched companies, the information from clients usually contributed to the modernization and faster development of previously existing technologies. In one case, customers were the direct inspiration for the development of new solutions, which were developed to better satisfy their needs.

A number of innovations appeared as a result of effective collaboration between external research institutions and businesses. However, such cooperation was not frequently established. Only 2 companies pointed out that universities can be classified as a source of their new environmentally friendly technologies. Nevertheless, if such cooperation took place, it was positively evaluated by entrepreneurs.

$3 / 4$ of the researched companies believe that the motivation for the creation of innovations can be drawn not only from the industry but also from the wider business environment, including media, trade shows and textbooks. They find mass media 
and socially available resources very inspiring. The information from the Internet, television and newspapers can guarantee companies' knowledge of technology available among different industries and global technological innovations. It often happens that this information influences functionality and improvements of ecoinnovations among companies-suppliers of environmentally sound technologies in Poland.

\subsection{Eco-Innovations Characteristics}

Determinants of eco-innovations, as well as different motivations and inspirations, resulted in the development of various types of eco-innovative solutions. The interviews show that $90 \%$ of the created products have the characteristics typical for novelties. $42,5 \%$ of the interviewed companies (17 companies) claimed that their eco-innovation, at the moment of the creation, was undoubtedly an innovation in a global scale. $25 \%$ of companies (10 companies) described the technology as new on the Polish market. Among the technologies that have been described as unique in the Polish market, there are also those, that were developed parallel to the global solutions. In rare cases, it happened that the engineers were working on a solution with no awareness that another group of researchers in other countries had come up with a similar idea earlier.

Among eco-innovations that have been created by the companies-suppliers of environmentally sound technologies in Poland, two are the ones that were not unique, at the world or the country level. The reason why such situation occurred, according to interviewees, is that there are some technological areas and industries in which, based on the present state of knowledge, there is no more space and possibility for creating innovation.

\section{Discussion}

The empirical research conducted among the selected Polish enterprises provides the evidence that there are many determinants of eco-innovations in the environmentally sound technologies industry in Poland. These factors can be classified on the basis of both the concept of innovation sources applied in theory to general innovations and the specific clas- sification of the determinants of eco-innovations provided by the researchers who study the topic of environmental innovations (Horbach, Rammer and Rennings, 2012). The research findings are generally in line with both theoretical frameworks (see: Figure 4).

The interviewed companies can be a good example of the technological approach to the determinants of eco-innovation, according to which research and development activities carried out within the firms result in the improvement of their technological performance and influence their eco-innovativeness (Horbach, 2008).

The second most important group of determinants of eco-innovation among the companies from the sample was related to the market factors, mainly customers and competitors. Contrary to other empirical studies (Demirel and Kesidou, 2012; Rehfeld, Rennings and Ziegler, 2007) customers in Poland influence the companies to undertake actions in order to develop new solutions. Enterprises declared that such approach was fruitful for both the companies which developed their solution and the users, who were able to get the product that fully served their needs. However, customers were rarely directly involved in the process of eco-innovation development. This phenomenon of customers playing the key role in motivating firms for the eco-innovations creation in Poland, but rarely taking part in the process of elaborating these new solutions, can be caused by the fact that environmentally sound technologies awareness and market in Poland are still pre-mature and relatively new. As companies develop mainly inhouse solutions and do not seek for international cooperation in the phase of product development, customers are strongly motivated to look for the products that may serve their needs on the domestic market. It also should be taken into account that the process of creation of many of the products offered by the interviewed companies started at the time of economic transformation of the Polish market, when the ability to seek for products abroad was to some extent limited. This is the second reason why there were some determined customers who were more willing to work together with the innovators on their products. The supply side of the market also 
Figure 4. Sources of eco-innovations: summary of the results of empirical research concerning sources contributing to the development of product eco-innovations by companies-suppliers of environmentally sound technologies in Poland compared with the literature and similar empirical studies of other authors
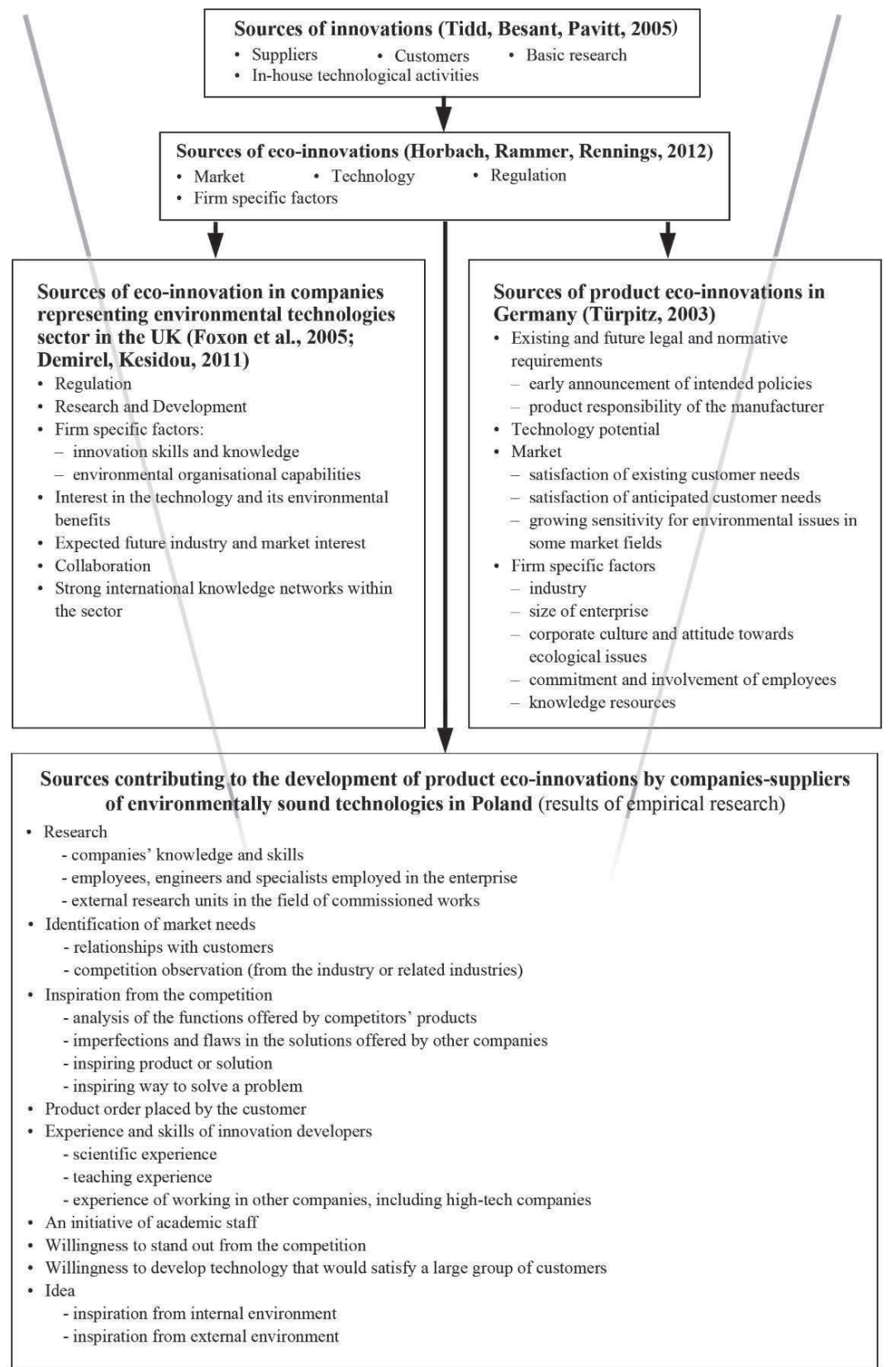

Explanations: Grey lines on the drawing (shown as tapering funnel) show a narrowed and more precise approach to identifying sources, the transition from general to specific (from all sources of innovation to the sources of specific types of innovations).

Source: Marczewska (2016, p. 165).

Wydział Zarządzania UW ～DOI 10.7172/1733-9758.2016.22.1 
seems to be an important source of inspiration which led to the development of novelties. In general, market research is seen as highly important in the development of eco-innovative products.

Another determinant that was found to be important for the creation of ecoinnovations in Poland lies inside the company. Firm specific factors including the resources gathered in the company played a significant role in Polish enterprises. The respondents have noted that the most important of these factors is the knowledge and experience of employees and inventors of an eco-innovation. In many cases people who contributed to the development of environmentally friendly technologies were former or current academics and also had an experience in multinational and domestic environmental industry or advanced technology firms. At this point, in the case of Polish companies, two groups of determinants of eco-innovative activity, technology and firm specific factors, coincide with each other as in many cases the previous experience of inventors highly influenced the research carried out in the company.

The regulatory aspect has not been listed as a determinant of eco-innovations by any of the 40 Polish companies-suppliers of environmentally sound technologies. The evidence provided by the research is according to this aspect in opposition to the findings of Brunnermeier and Cohen (2003), Rennings (2000), Triguero, Moreno-Mondéjar and Davia (2013) and Horbach, Rammer and Rennings (2012). However, this finding of the empirical research could be justified bu the approach proposed by Oltra (2008) and Cleff and Rennings (1999), who claim that regulatory aspect should be treated as supportive, to market pull and technology push factors. In the case of Polish companies, market and technological determinants are the core ones, so the lack of regulatory aspect in the respondents' interviews might be caused by the fact that it does not directly influence the creation of eco-innovations, but it is only the support for other determinants, as stated in the literature. Another possible explanation of this result comes from the nature of eco-innovations considered. Companies from the sample are suppliers of environmentally sound technologies, so new solutions developed by them are product innovations. The regulatory aspect is usually more important in the case of process innovations (Ghisetti and Rennings, 2014; Horbach, 2008).

\section{Conclusions and Future Research Directions}

The results of the study rely on its original contribution about the drivers and basic characteristics of one type of eco-innovation (product eco-innovation) developed by a sample of specific market players, i.e. companies-suppliers of environmentally sound technologies. The explorative study of motivations and determinants for the development of eco-innovation in Polish companies is performed partly in the context of an economy in transition. From a pan-European perspective, the topic of drivers for the development of eco-innovations in Eastern European perspective is highly needed. One of the major findings is based on the national characteristics of innovation activities in this country. The restrictions on access to foreign green products and environmental technologies created an endogenous national capacity that is currently used by (a sample of) firms to successfully compete in the market. It is worth noting that similar events happened in the process of re-industrialization and development of technological capabilities in developing countries (c.f. Lall, 1987, 1992; Bell, 1984; etc.).

Based on the interviews conducted with the selected 40 companies, it is possible to specify the determinants and sources of eco-innovative activity and the motivation for creating eco-innovations in Poland. They are mainly market- and technology-related factors. This conclusion is in line with the studies emphasizing the role of market, technology and firm specific factors as the determinants of eco-innovations, but in opposition to the results supporting the thesis that regulatory aspect is highly important for the companies that create and develop environmentally friendly novelties.

The paper also shows that the main motivation and inspiration of eco-innovative activity in Poland is the market behaviour of competitors. More than half of the companies from the sample state 
that they drew inspiration from similar solutions developed by other companies. However, in most cases the inspiration was not aimed at copying existing successful ideas, but gaining knowledge about their features and weaknesses. At the same time, 27 of interviewed enterprises in their eco-innovation activity rely mainly on their own internal R\&D activity. Just a few enterprises declare that there is some cooperation with universities and research organizations. New ideas developed by research institutions are rarely used by the companies.

Furthermore, there is a high pressure coming from policy makers on enterprises to implement ecological solutions, partly induced by the European Union policy. There is also a growing flow of public funds supporting eco-innovativeness. However, awareness about the need to be eco-efficient is still relatively low among Polish enterprises.

The results (and overall findings of the paper) should be treated as explorative. The reason for this is that its discussion and conclusions are based on a sample of 40 company-level interviews. Hence the level of generalization of results needs to be carefully established.

Since the evidence of this research cannot be applied to the whole population of companies, because the interviewed population included the suppliers of their own, advanced environmentally sound technologies in Poland, while amongst other enterprises from the sector, there are also distributors of technologies or manufacturers of less advanced solutions, there is a need for further research of this complex phenomenon. The next step of such study could be multiple case study research on the basis of which it will be possible to discover and analyse in depth the reasons why some determinants are more important than others, and explain the lack of the regulatory aspect amongst these factors.

\section{Footnote}

1 The work has been supported by the Polish National Science Centre (pl. Narodowe Centrum Nauki) funds allocated with the decision DEC-2014/12/T/HS4/00311.

\section{Referencess}

Andersen, M.M. (2008). Eco-innovation-towards a taxonomy and theory. 25th Celebration Conference 2008 on entrepreneurship and innovation - organizations, institutions, systems and regions, Denmark. Aragon-Correa, J.A. and Sharma, S. (2003). A contingent resource-based view of proactive corporate environmental strategy. Academy of Management Review, 28(1), 71-88.

Banerjee, S.B., Iyer, E.S. and Kashyap, R.K. (2003). Corporate environmentalism, antecedents and influence of industry type. Journal of Marketing, 67(2), 106-122.

Belin, J., Horbach, J. and Oltra, V. (2009). Determinants and specificities of eco-innovations - An econometric analysis for France and Germany based on the Community Innovation Survey. DIME.

Bell, M. (1984). Learning and the accumulation on industrial technological capacity in developing countries. In: M. Fransman and K. King (eds.). Technological capacity in the third world (pp. 187-209). Basingstone: The Macmillan Press Ltd.

Białoń, L. (ed.). (2010). Zarzadzanie działalnościa innowacyjna. Warszawa: Placet.

Brunnermeier, S.B. and Cohen, M.A. (2003). Determinants of environmental innovation in US manufacturing industries. Journal of Environmental Economics and Management, 45, 278-293.

Carrillo-Hermosilla, J., Del Río, P. and Könnölä, T. (2009). Eco-innovation. When sustainability and competitiveness shake hands. New York: Palgrave Macmillan.

Carrillo-Hermosilla, J.H., Del Río, P. and Könnölä, T. (2010). Diversity of eco-innovations: Reflections from selected case studies. Journal of Cleaner Production, 18, 1073-1083.

Cheng, C.C.J., Yang, C.L. and Sheu, C. (2014). The link between eco-innovation and business performance: A Taiwanese industry context. Journal of Cleaner Production, 64(1), 81-90.

Chrząścik, I., Marciniuk-Kluska, A. and Kluska, M. (2010). Ekoinnowacje a zrównoważony rozwój. Studia Ecologiae et Bioethicae, 8(1), 169-177.

Cleff, T. and Rennings, K. (1999). Determinants of environmental product and process innovation. European Environment, 9, 191-201.

Corbin, J. and Strauss, A. (1990). Grounded Theory Research: Procedures, Canons, and Evaluative Criteria. Qualitative Sociology, 13(1), 3-21.

Cuerva, M.C., Triguero-Cano, A. and Córcoles, D. (2013). Drivers of green and non-green innovation: empirical evidence in Low-Tech SMEs. Journal of Cleaner Production, 68, 104-113.

Del Val Segarra-Oña, M. and Peiró-Signes, A. (2013). Eco-innovation determinants in service industries. Direccion y Organizacion, 50, 5-16. 
Demirel, P. and Kesidou, E. (2012). On the drivers of eco-innovations: Empirical evidence from the UK. Research Policy, 41, 862-870.

Demirel, P., Kesidou, E. (2011). Stimulating different types of eco-innovation in the UK: governmen policies and firm motivations. Ecological Economics, 70, 1546-1557.

Díaz-García, C., González-Moreno, Á. and Sáez-Martínez, F.J. (2015). Eco-innovation: insights from a literature review. Innovation: Management, Policy \& Practice, 17(1), 6-23.

Drucker, P.F. (1992). Innowacja i przedsiębiorczość. Praktyka i zasady. Warszawa: PWE.

Drucker, P.F. (2004). Natchnienie $i$ fart, czyli innowacja i przedsiębiorczość. Warszawa: Wydawnictwo Studio Emka.

Ekins, P. (2010). Eco-innovation for environmental sustainability: concepts, progress and policies. International Economics and Economic Policy, 7(2), 267-290.

Elkington, J. (1998). Cannibals with forks: the triple bottom line of 21st century business. Stony Creek, CT: New Society Publishers.

Flick, U. (2011). Jakość w badaniach jakościowych. Warszawa: Wydawnictwo Naukowe PWN.

Foxon, T.J., Gross, R., Chase, A., Howes, J., Arnall, A. and Anderson, D. (2005). UK innovation systems for new and renewable energy technologies: drivers, barriers and systems failures. Energy Policy, 33, 2123-2137.

Freeman, Ch. (1982). The Economics of Industrial Innovation. London: Pinter.

Frieder, R., Dirk, S. and Fabio, I. (2008). Ecolabelling and product development: potentials and experiences. International Journal of Product Development, 6(3/4), 393-419.

Fussler, C. and James, P. (1996). Eco-innovation: A Breakthrough Discipline for Innovation and Sustainability. London: Pitman Publishing.

Ghisetti, C. and Rennings, C. (2014). How does it pay to be green? An empirical analysis on the German Innovation Survey. Journal of Cleaner Production, 75, 106-117.

Giancarlo, B. (2007). Eco-effectiveness to pursue resource valorisation and conservation: a new approach. International Journal of Environmental Technology and Management, 7(5/6), 734-742.

Glaser, B. and Strauss, A. (2006). The Discovery of Grounded Theory. Strategies for Qualitative Research. New Brunswick, London: Aldine Transaction.

Griffin, R.W. (1996). Podstawy zarzadzania organizacjami. Warszawa: Wydawnictwo Naukowe PWN.

Grudzewski, W.M. and Hejduk, I.K. (2008). Zarzadzanie technologiami. Zaawansowane tech- nologie $i$ wyzwanie ich komercjalizacji. Warszawa: Centrum Doradztwa i Informacji Difin.

Hart, S.L. (1995). A natural resource-based view of the firm. The Academy of Management Review, 20(4), 986-1014.

Horbach, J. (2008). Determinants of environmental innovation - New evidence from German panel data sources. Research Policy, 37, 163-173.

Horbach, J. (2013). Do eco-innovations need specific regional characteristics? 35th DRUID Celebration Conference 2013, Barcelona.

Horbach, J., Rammer, C. and Rennings, K. (2012). Determinants of eco-innovations by type of environmental impact. The role of regulatory push/ pull, technology push and market pull. Ecological Economics, 78, 112-122.

James, P. (1997). The sustainability circle: a new tool for product development and design. Journal of Sustainable Product Design, 2, 52-57.

Janasz, W. and Kozioł, K. (2007). Determinanty działalności innowacyjnej przedsiębiorstw. Warszawa: PWE.

Janasz, W. and Leśkiewicz, I. (1995). Identyfikacja i realizacja procesów innowacyjnych $w$ przedsiębior stwie. Szczecin: Uniwersytet Szczeciński.

Jänicke, M. (2012). "Green growth”: From a growing eco-industry to economic sustainability. Energy Policy, 48, 13-21.

Kammerer, D. (2009). The effects of customer benefit and regulation on environmental product innovation. Empirical evidence from appliance manufacturers in Germany. Ecological Economics, 68, 2285-2295.

Kanerva, M., Arundel, A. and Kemp, R. (2009) Environmental innovation: Using qualitative models to identify indicators for policy. United Nations University Working Papers Series, Maastricht.

Kemp, R. (2010). Eco-innovation: Definition, measurement and open research issues. Economia Politica, 27, 397-420.

Kemp, R. and Pearson, P. (2007). Final report MEI project about measuring eco-innovation. Maastrich Economic and Social Research Institute on Innovation and Technology, Maastricht.

Kevin, B. and Patrice, H. (1999). Sustainability, Eco-efficiency, Life-Cycle Management, and Business Strategy. Environmental Quality Management, 8(3), 33-41.

Kline, J. and Rosenberg, N. (1986). An overview of Innovation. In: R. Landau and N. Rosenberg (eds.) The Positive Sum Strategy. Harnessing Technology for Economic Growth (pp. 275-306). Washington D.C.: National Academy Press.

Kotler, P. (2000). Marketing Management. Boston: Pearson Custom Publishing. 
Lall, S. (1987). Learning to Industrialize: The Acquisition of Technological Capability by India. London: Macmillan.

Lall, S. (1992). Technological Capabilities and Industrialization. World Development, 20(2), 165-186.

Marczewska, M. (2016). Źródta i mechanizmy powstawania ekoinnowacji $w$ przedsiębiorstwach dostawcach technologii środowiskowych. Warszawa: Difin.

Matejun, M. (2009). Zarządzanie innowacjam ekologicznymi we współczesnym przedsiębiorstwie. In: R. Grądzki and M. Matejun (eds.). Rozwój zrównoważony - zarzadzanie innowacjami ekologicznymi (pp. 19-31). Łódź: Wydawnictwo Media Press.

OECD. (2005). Oslo Manual. Guidelines for collecting and interpreting innovation data, third edition. Paris: OECD and Eurostat.

Oltra, V. (2008). Environmental innovation and industrial dynamics the contributions of evolutionary economics. Working Papers of GREThA, 28, 1-26.

Penc, J. (1999). Innowacje i zmiany w firmie. Transformacja $i$ sterowanie rozwojem przedsiębiorstwa. Warszawa: Agencja Wydawnicza Placet.

Pinar, E. and Jorg, T. (2005). ECO-design of reuse and recycling networks by multi-objective optimization. Journal of Cleaner Production, 13(15), 1449-1460.

Piotrowska, J. (2012). Ekoinnowacje - wyzwanie dla polskiej gospodarki. Studia i Prace Wydziatu Nauk Ekonomicznych $i$ Zarzadzania Uniwersytetu Szczecińskiego, 28, 173-187.

Porter, M.E. (2008). On Competition. Boston: Harvard Business Review.

Prothero, A. and McDonagh, P. (1992). Producing environmentally acceptable cosmetics? The impact of environmentalism on the United Kingdom cosmetics and toiletries industry. Journal of Marketing Management, 8(2), 147-166.

Przychodzeń, J. (2015). Ekoinnowacje w przedsiębiorstwie. Zarządzanie, pomiar i wpływ na wyniki finansowe. Warszawa: CeDeWu.

Pujari, D., Wright, G. and Peattie, K. (2003). Green and competitive: influences on environmental new product development (ENPD) performance. Journal of Business Research, 56(8), 657-671.

Rehfeld, K.M., Rennings, K. and Ziegler, A. (2007) Integrated product policy and environmental product innovations: An empirical analysis. Ecological Economics, 61(1), 91-100.

Rennings, K. (2000). Redefining innovation - ecoinnovation research and the contribution from ecological economics. Ecological Economics, 32, 319-332.
Rogers, E.M. (2003). Diffusion of Innovations. New York: The Free Press.

Rothwell, R. and Gardiner, P. (1983). The Role of Design on Product and Process Change. Design Studies, 4(3), 161-169.

Rothwell, R. and Zegveld, W. (1985). Reindustrialization and Technology. London: Longman.

Ryszko, A. (2016). Interorganizational cooperation, knowledge sharing, and technological eco-innovation: The role of proactive environmental strategy - empirical evidence from poland. Polish Journal of Environmental Studies, 25(2), 753-764.

Schmookler, J. (1966). Invention and Economic Growth. Cambridge: Harvard University Press.

Schumpeter, J.A. (1939). Business Cycles. New York, London: McGraw Hill.

Schumpeter, J.A. (1960). Teoria rozwoju gospodarczego. Warszawa: PWN

Seroka-Stolka, O. (2012). Wzrost konkurencyjności przedsiebiorstwa w oparciu o jego ekoinnowacyjność. Zeszyty Naukowe Wyższej Szkoty Humanitas. Zarządzanie, 13(2), 189-198.

Sharma, S. (2000). Managerial interpretations and organizational context as predictors of corporate choice of environmental strategy. Academy of Management Journal, 43(4), 681-197.

Siedlecka, E.M. (2014). Ekoinnowacje w technologii i organizacji przedsiębiorstw. Gdańsk: Uniwersytet Gdański.

Szpor, A. and Śniegocki, A. (2012). Ekoinnowacje $w$ Polsce. Stan obecny, bariery rozwoju, możliwo ści wsparcia. Warszawa: Instytut Badań Strukturalnych.

Tidd, J., Bessant, J. and Pavitt, K. (2005). Managing Innovation Integrating Technological, Market and Organizational Change. West Sussex: John Wiley \& Sons.

Triguero, A., Moreno-Mondéjar, L. and Davia, M.A. (2013). Drivers of different types of eco-innovation in European SMEs. Ecological Economics, $92,25-33$.

Türpitz, K. (2003). The determinants and effects of environmental product innovations. Conference Paper, Greening of Industry Network International Conference, San Francisco.

Urbaniec, M. (2015). Towards sustainable development through ecoinnovations: Drivers and barriers in poland. Economics and Sociology, 8(4), 179-190.

Vergragt, P., Akenji, L. and Dewick, P. (2014). Sustainable production, consumption, and livelihoods global and regional research perspectives. Journal of Cleaner Production, 63, 1-12.

Von Hippel, E. (1988). The Sources of Innovation. New York, Oxford: Oxford University Press. 
Węgrzyn, G. (2013). Ekoinnowacje w Polsce na tle krajów Unii Europejskiej. Ekonomia i Środowisko, 3(46), 138-148.

Whitfield, P.R. (1979). Innowacje w przemyśle. Warszawa: PWN.

Woźniak, L., Strojny, J. and Wojnicka, E. (2010) Ekoinnowacje $w$ praktyce funkcjonowania MŚP. Warszawa: Polska Agencja Rozwoju Przedsiębiorczości.
Ziółko, M. and Mróz, J. (2015). Wpływ ekoinnowacji na wzrost konkurencyjności przedsiebiorstw. Acta Universitatis Nicolai Copernici - Zarzadzanie, 1, 73-84.

Zuzek, D.K. (2015). Determinanty rozwoju ekoinnowacji w sektorze MSP na przykładzie województwa małopolskiego. Roczniki Naukowe Stowarzyszenia Ekonomistów Rolnictwa i Agrobiznesu, XVII(1), 240-244. 